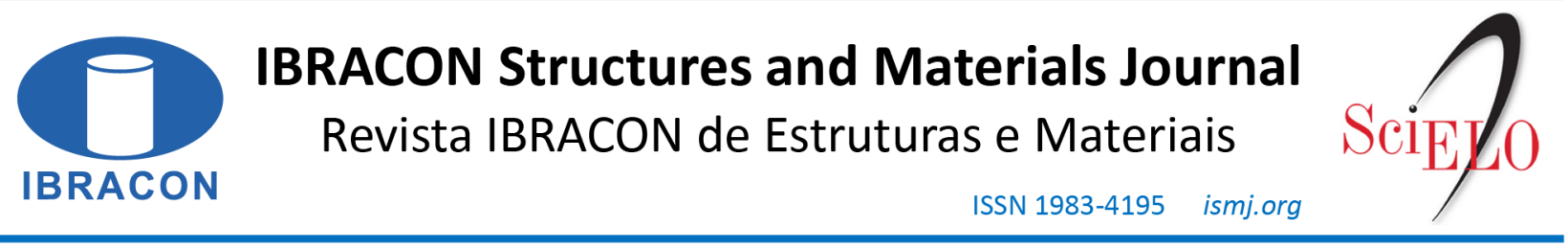

ORIGINAL ARTICLE

\title{
Numerical modeling and design of precast prestressed UHPFRC I beams
}

\section{Modelagem numérica e projeto de vigas I protendidas de UHPFRC}

\author{
Gustavo de Miranda Saleme Gidrão ${ }^{\mathrm{a}}$ (i) \\ Pablo Augusto Krahl ${ }^{\mathrm{b}}$ (i) \\ Ricardo Carrazedo ${ }^{\mathrm{c}}$
}

aUniversidade Tecnológica Federal do Paraná - UTFPR, Departamento de Engenharia Civil, Guarapuava, PR, Brasil

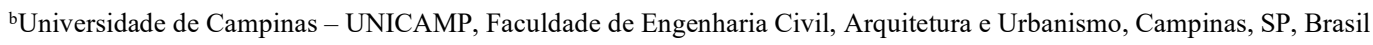

'Universidade de São Paulo - USP, Escola de Engenharia de São Carlos - EESC, Departamento de Estruturas, São Carlos, SP, Brasil

Received 30 September 2018

Accepted 16 August 2020

\begin{abstract}
Ultra-high-performance fiber reinforced concrete (UHPFRC) is a new material developed to present superior properties, as high compressive strength (higher than $130 \mathrm{MPa}$ ), high durability, and satisfactory ductile behavior. This paper reports the procedure to design precast UHPFRC beams, subject to flexural loads. First, an I-girder AASHTO Type II was designed, and simulated. Next, I-beams with diverse depths and steel ratios were designed, and simulated considering a four-point bending load test. It was found that the classical design equations used to predict the strength bending moment $\left(\mathrm{M}_{\mathrm{rd}}\right)$ showed good accuracy with the simulated models with a $4.5 \%$ error.
\end{abstract}

Keywords: UHPFRC, design, precast, flexural failure.

\begin{abstract}
Resumo: O Concreto de ultra alto desempenho reforçado por fibras (CUADRF ou Ultra-high performance fiber reinforced concrete - UHPFRC) é um novo material desenvolvido para apresentar propriedades superiores, tais como altas resistências à compressão (superior a $130 \mathrm{MPa}$ ), grande durabilidade, além de comportamento dúctil satisfatório em situações de flexão. Atualmente, nota-se a crescente tendência de aplicação deste material na indústria de pré-moldados, sendo necessário o entendimento sobre o procedimento básico que rege o dimensionamento destas peças. O presente artigo reporta sobre o procedimento de cálculo para dimensionamento de uma viga pré-moldada protendida constituído de UHPFRC, sob condições de Estado Limite Último flexional. A viga estudada é do tipo "I" AASHTO Tipo II, com 26 cabos protendidos. Esta viga é simulada numericamente via software de elementos finitos e comparada com um resultado experimental reportado na literatura, verificando-se os mecanismos de falha para o elemento estrutural, e assim validando o modelo numérico proposto. Em seguida, são simuladas vigas I com altura e armaduras ativas variáveis. Após as simulações, equações clássicas de dimensionamento são utilizadas para previsão de momento resistente $\left(\mathrm{M}_{\mathrm{Rd}}\right)$, apresentando grande precisão com erro relativo menor que 4,5\%.
\end{abstract}

Palavras-chave: UHPFRC, dimensionamento, pré moldados, estado limite último de flexão.

How to cite: G. M. S. Gidrão, P. A. Krahl, and R. Carrazedo, "Numerical modeling and design of precast prestressed UHPFRC I beams," Rev. IBRACON Estrut. Mater., vol. 14, no. 3, e14310, 2021, https://doi.org/10.1590/S1983-41952021000300010

\section{INTRODUCTION}

In 1993, Richard and Cherezy developed the Reactive Powder Concrete (RPC), using fine particles, mineral additions, and thermal treatment [1], [2]. RPC presented high durability levels and high strength, characteristics obtained due to the rigorous material selection, grain packing, and standard proceeding mixture [3], [4]. In this way, RPC presented compression strength around $150-200 \mathrm{MPa}$ [1], [2], [5] and porosity levels below 4\% [6].

Corresponding author: Gustavo de Miranda Saleme Gidrão. E-mail: gustavo.gidrao@gmail.com

Financial support: The authors gratefully acknowledge the financial support (grant ID - 141993/2014-6) provided by National Counsel of Technological and Scientific Development (CNPq) from Brazil.

Conflict of interest: Nothing to declare. 
The notable advances of superplasticizers and mineral additions allowed the production of concretes with high volumetric amounts of fine particles, perfectly packed and with low water-cement ratios allowing the development of the precursor Ultra-High-Performance Concrete (UHPC) [6]-[8]. UHPC presents (i) high mechanical properties in the long term, (ii) low permeability, and (iii) long life cycle under aggressive environments [6], [9].

Therefore, UHPC must present a water-cement ratio of around 0.2 and a minimum compressive strength of 130 $\mathrm{MPa}$ at 28 days [10], [11]. However, the matrix densification and decrease of microstructure imperfections may induce brittle failure of the elements that present low ductility due to its reduced tensile strength. The mitigation of brittle failures, metallic microfibers are added to the mixture, improving the ductile behavior, and then UHPC is named UHPFRC [7].

Considering its elevated properties, durability, and appropriated workability, UHPFRC is an emergent material with notable applications in the precast industry [7], [12]-[14]. Given this context, this paper describes a procedure for designing UHPFRC elements subjected to bending loads. The analytical results obtained with the proposed equations are compared to numerical simulation results of beams constituted of UHPFRC, presenting good accuracy.

\section{BENDING DESIGN}

Fehling et al. [7], [15] proposed basic assumptions and analytical equations to design UHPC and UHPFRC elements subjected to flexural loads. Figure 1 presents the stress-strain distribution of the rectangular beam studied by Fehling et al. [7], [15] considering axial force $\left(\mathrm{N}_{\mathrm{sd}}\right)$ and bending moment $\left(\mathrm{M}_{\mathrm{sd}}\right)$ :

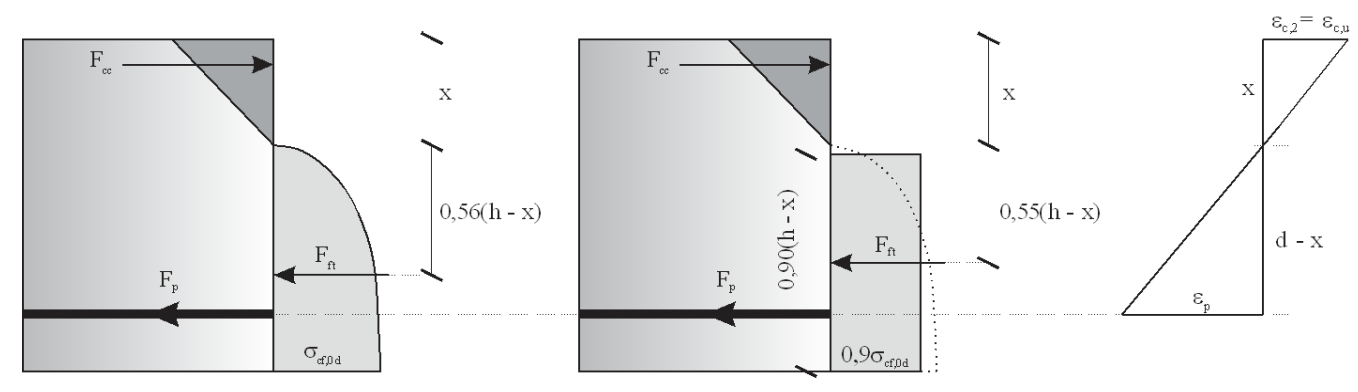

(a) Parabolic distribution (b) equivalent rectangular distribution (c) Strain compatibility

Figure 1. Stress distribution (a and b) and strain (c) for a rectangular cross-section (Fehling et al. [7])

In Figure 1, $\mathrm{x}$ is the neutral axis position; $\mathrm{F}_{\mathrm{cc}}$ is the concrete compressive resultant force located at a distance equal to $\mathrm{x} / 3$ from the top; $\mathrm{F}_{\mathrm{ft}}$ is the concrete tensile force located at the centroid of the parabolic area representing the stress distribution; and $\mathrm{F}_{\mathrm{st}}$ is the resultant steel force.

The herein presented assumptions are considered to develop the design equations:

- Bernoulli hypothesis: plane sections remain plane, and the deformed beam angles are small.

- Triangular compressive stress distribution is considered with a linear stress-strain compressive response for the concrete until the failure (see e.g., Figure 1).

- Tensile stress cannot be disregarded for UHPFRC, and its distribution can be considered parabolic (Figure 1a) or rectangular (Figure 1b)

The concrete tensile resultant force can be calculated by integrating the area of the stress distribution. Equation 1 indicates the resultant force considering a parabolic stress distribution. The resultant force is located at the centroid of the parabolic area from a distance equal to $0.56(\mathrm{~h}-\mathrm{x})$ to the neutral axis [7], [15]. Equation 2 indicates the concrete tensile force considering a rectangular distribution. Comparing Equations 1 and 2, it can be observed an error smaller than $2.5 \%$. Hence, for simplicity, this paper considers the rectangular distribution for concrete tensile stresses, according to Equation 2.

$F_{f t}=0.83 \cdot(h-x) \cdot b \cdot \sigma_{c f 0 d}$ 
$F_{f t}=0.81 \cdot(h-x) \cdot b \cdot \sigma_{c f 0 d}$

In Equation 2, $\mathrm{h}$ is the beam height, $\mathrm{x}$ is the depth of the neutral axis, $\mathrm{b}$ is the beam width, $\sigma_{\mathrm{cf}, 0 \mathrm{~d}}$ is the direct tensile strength.

Equation 3 gives the resultant compressive force $\left(\mathrm{F}_{\mathrm{cc}}\right)$, and Equation 4 presents the resultant force applied to the prestressed cables $\left(\mathrm{F}_{\mathrm{st}}\right)$ calculates using the stress-strain diagram of the steel cables.

$F_{c c}=0.50 \cdot b \cdot x \cdot f_{c d}$

$F_{s t}=A_{s t} \cdot \sigma_{s t}$

The equilibrium equations in terms of the axial forces and bending moments are given by Equations 5 and 6 , respectively,

$\Sigma F=0=N_{S d}+F_{c c}-F_{f t}-F_{s t}$

$\Sigma M=0=M_{S d}-F_{c c} \cdot(d-x / 3)+F_{f t} \cdot(d-0,45 \cdot x-0,55 \cdot h)$

Finally, it is necessary to impose a strain compatibility relationship for the cross-section (Equation 7). Figure 1c shows the strain response along with the height of the section, considering the cables embedded in the concrete.

$\frac{\varepsilon_{c}}{x}=\frac{\varepsilon_{s t}}{d-x}$

In Equation 7, $\left(\varepsilon_{\mathrm{st}}\right)$ is the tensile strain at the reinforcement and $\left(\varepsilon_{\mathrm{c}}\right)$ the compressive strain of the concrete.

Finally, following the above-suggested steps, it is possible to design a beam with arbitrary dimensions (Figure 2),

1. Calculate the resultant axial forces: $F_{\mathrm{ft}}, \mathrm{F}_{\mathrm{cc}}, \mathrm{F}_{\mathrm{sc}}$ e $\mathrm{F}_{\mathrm{st}}$;

2. Define the depth of the neutral axis ( $\mathrm{x}$ ) using an iterative algorithm to promote the equilibrium of bending moments in the cross-section;

3. Update resultant forces at concrete and steel cables $F_{\mathrm{cc}}$ and $\mathrm{F}_{\mathrm{ft}}$;

4. Impose the compatibility relationship to calculate the strains along with the cross-section height;

5. Determine the stress in the reinforcements $\sigma_{\mathrm{s}, \mathrm{t}}$ using the constitutive stress-strain relation;

6. Calculate the required reinforcement area $\left(\mathrm{A}_{\mathrm{st}}\right)$;

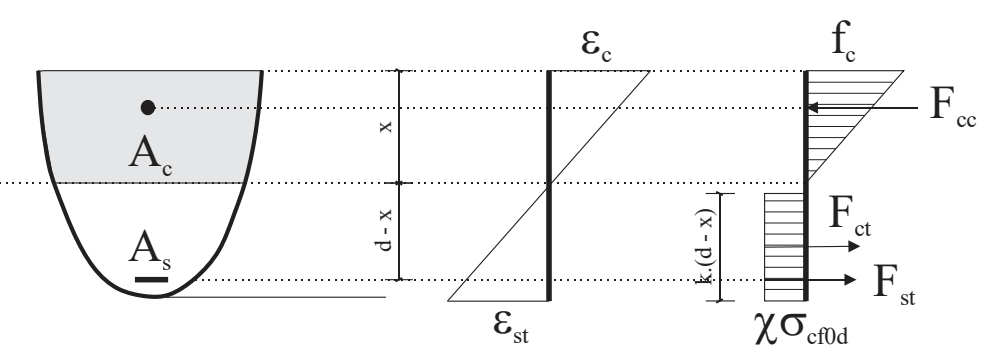

Where:

$\mathrm{k}=0.9$

$\chi=0.85$ if the width of the cross-section decreases towards the tensile edge $\chi=0.90$ in general

Figure 2. Design model to an arbitrary cross-section 


\section{CASES OF STUDY}

In this section, the numerical and experimental results showed by Graybeal [16] are used to validate the proposed method for designing UHPFRC elements (section 2). The example consists of an I-beam PCI AASHTO II constituted by UHPFRC with 26 prestressed steel reinforcements and subjected to a bending test, according to Figure $3 \mathrm{a}$ and $3 \mathrm{~b}$. This section is commonly applied to bridge structures using C70 concrete. The Graybeal's experimental results were used to calibrate a Finite Elements Model (FEM) using Concrete Damage Plasticity (CDP) to describe the non-linear behavior of the material, presented in Section 5.1.

Moreover, aiming to test the capability of the analytical equations proposed by Fehling et al. [7], [15], the strength of prestressed sections are predicted using a numerical FEM model and analytical model. These beams present heights $\mathrm{h}=500 \mathrm{~mm}, 400 \mathrm{~mm}$ and $300 \mathrm{~mm}$, two reinforcement strands $(\phi=12,5 \mathrm{~mm})$ placed in the inferior flange, constant width $b=300 \mathrm{~mm}$ and constant thickness $\mathrm{e}=50 \mathrm{~mm}$, according to Figure $3 \mathrm{c}$. The spans of the beams are 3 meters, and the point load application and boundary conditions are described in Figure 3d. The UHPFRC characteristics used in this analytical-numerical model were adopted, according to Krahl et al. [17], [18].

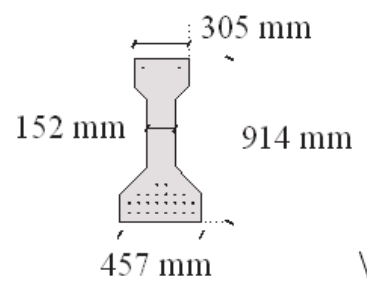

(a)

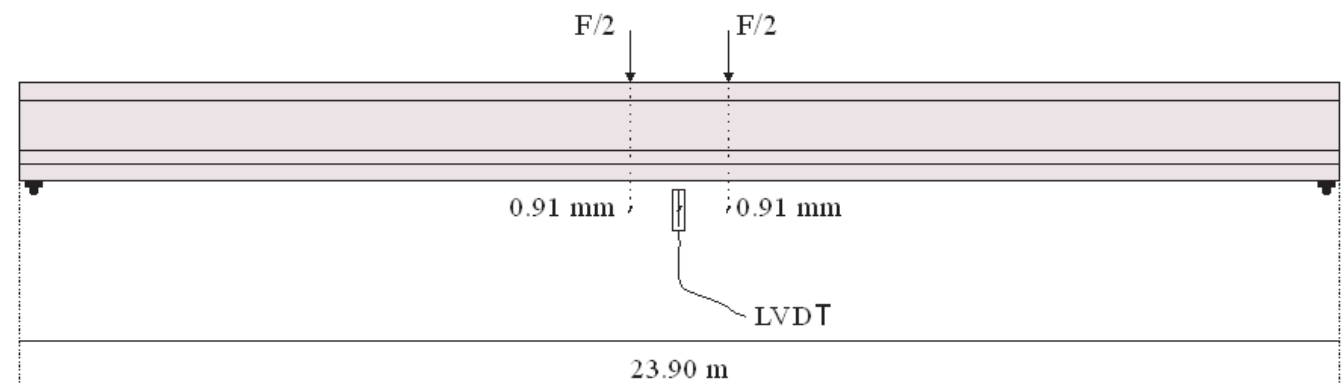

(b)
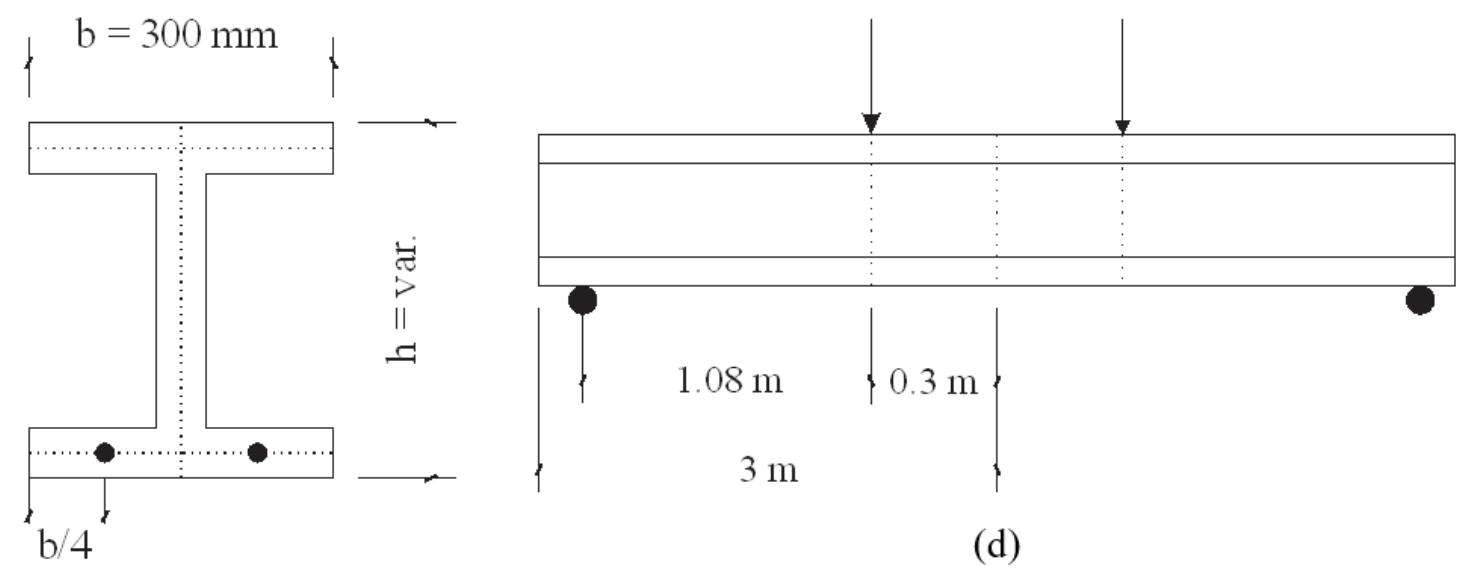

(d)

(c)

Figure 3. Studied girders: PCI AASHTO Type II: (a) cross-section, (b) Scheme test [15]. I-sections: (c) cross-section e (d) Scheme test. 
Table 1 presents the different material characteristics for UHPFRC produced by Krahl and Graybeal. It is relevant the fact of the Graybeal's concrete presents divergency in uniaxial tensile behavior, i.e.,: the value of 9MPa was presented by the author as the direct tensile strength, performed in dog bone samples [16]; and the value of 15.9MPa was presented as the calibrated uniaxial response of numerical model [16]. In this paper, we are showing the results obtained, considering these two different tensile strengths to analyze. Hence, the first girder "Complete Graybeal model" was simulated using the tensile strength of $15.9 \mathrm{MPa}$ and considering the tensile and compressive uniaxial behaviors; and "Simplified Graybeal model" was modeled using the tensile strength of $9 \mathrm{MPa}$ and a simplified uniaxial tensile law based in the direct tensile tests.

Table 1. Design parameters

\begin{tabular}{|c|c|c|}
\hline Parameter & Graybeal & Krahl \\
\hline Compressive Strength $(\mathrm{MPa})-\mathrm{f}_{\mathrm{c}}$ & 193 & 145 \\
\hline Direct tensile strength (MPa) & $9 * *$ e $15.9 * * *$ & 6.9 \\
\hline Steel strength $(\mathrm{MPa})-\mathrm{f}_{\mathrm{p}, \mathrm{u}}$ & 1860 & 1860 \\
\hline Prestress $(\mathrm{MPa})-\mathrm{f}_{\mathrm{p}, \mathrm{i}}$ & 885 & 850 \\
\hline Prestresses strands diameter $(\mathrm{mm})-\phi$ & 12.7 & 12.7 \\
\hline Total area of the girder $\left(\mathrm{m}^{2}\right)$ & 0.23 & Var. \\
\hline$* \mathrm{~d}^{\prime}$ bot $(\mathrm{mm})$ & 102 & 25 \\
\hline$* \mathrm{~d}_{\text {top }}(\mathrm{mm})$ & 51 & - \\
\hline Steel Young Modulus - Es $(\mathrm{GPa})$ & 198 & 198 \\
\hline Concrete Young Modulus - $\mathrm{E}_{\mathrm{ci}}(\mathrm{GPa})$ & 55 & 55 \\
\hline Moment of Inertia $\left(\mathrm{m}^{4}\right)$ & 0.02 & Var. \\
\hline Girder Height (mm) & 914 & Var. \\
\hline
\end{tabular}

$* \mathrm{~d}$ ' is the distance of the top and bottom face until steel strands gravity center. $* *$ The value of 9 MPa is obtained by direct tensile test [16]. ***The value of 15.9 Mpa is obtained by numerical-experimental calibration [16]

\section{NUMERICAL SIMULATION}

\subsection{Graybeal's girder constitutive model}

The constitutive tensile law based on the calibrated tensile and compressive uniaxial behaviors given by Graybeal [16] is according to Figure 4a and b, with 15.9 MPa tensile strength. The second girder, "Simplified Graybeal model", was modeled using the tensile strength of $9 \mathrm{MPa}$ and a simplified uniaxial tensile law based on direct tensile tests; see Figure $4 \mathrm{~b}$ simplified model. The constitutive model of Concrete Damage Plasticity (implemented in ABAQUS CAE Simulia) was applied to simulate both girders. The compressive and tensile damage evolution (i.e., $d_{t}$ and $d_{c}$ ) are obtained by the methodology proposed by Birtel and Mark [19], through Equations 8 and 9:

$$
\begin{aligned}
& d_{t}=1-\frac{\sigma_{t} E_{c}^{-1}}{\varepsilon_{t}^{p l}\left(\frac{1}{b_{t}}-1\right)+\sigma_{t} E_{c}^{-1}} \\
& d_{c}=1-\frac{\sigma_{c} E_{c}^{-1}}{\varepsilon_{c}^{p l}\left(\frac{1}{b_{c}}-1\right)+\sigma_{c} E_{c}^{-1}}
\end{aligned}
$$




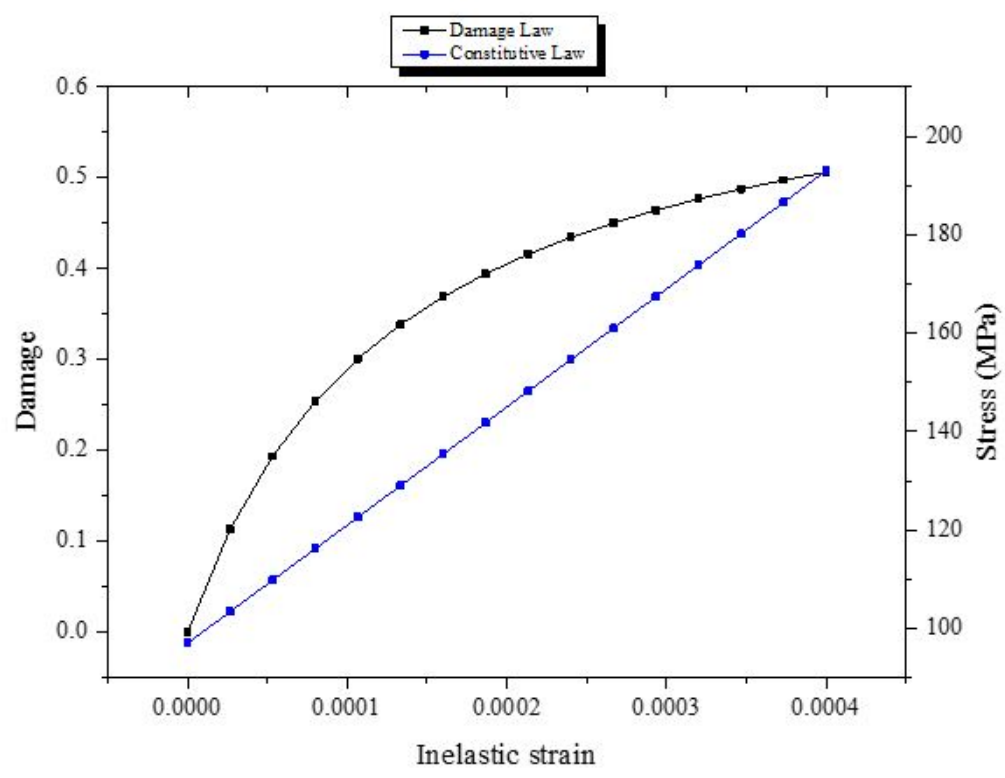

(a) Compressive uniaxial response

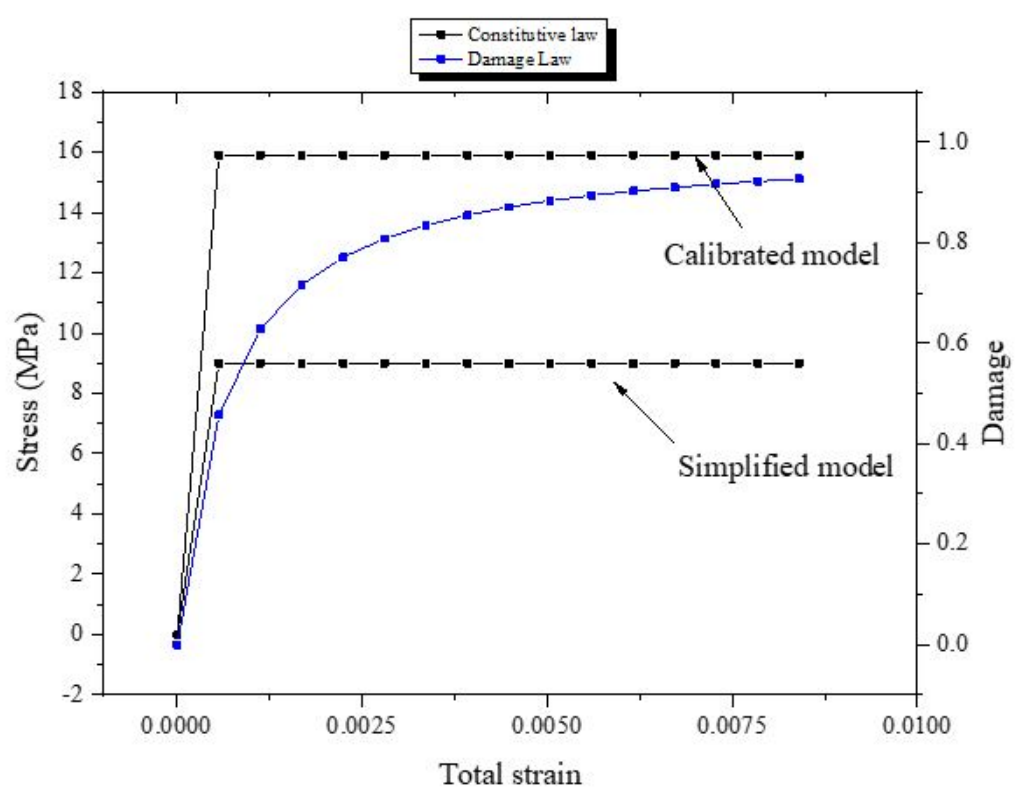

Figure 4. (a) e (b) UHPFRC Constitutive model - Graybeal [16]

In Equations 8 and 9 is the tensile stress of the concrete; $\sigma_{c}$ is the compressive stress of the concrete; $\mathrm{E}_{\mathrm{c}}$ is the elastic modulus of the intact material; $b_{c}=0.7$ and $b_{t}=0.57$ are empirical parameters related to damage evolution [19]; and are plastic strains, defined as $\varepsilon^{p l}=b_{c} \varepsilon^{i n}$, and $\varepsilon^{i n}$ is given by the difference between total and elastic deformation $\left(\sigma / \mathrm{E}_{\mathrm{c}}\right)$. Table 2 presents the elasticity and plasticity parameters adopted.

ASTM 270-ksi steel was used in prestressed strands, with the constitutive law given by Figure 5 [20]. A prestress load of $885 \mathrm{MPa}$ was adopted. The prestressed strands were considered totally embedded into the concrete. The steel elastic modulus is $\mathrm{E}_{\mathrm{s}}=197 \mathrm{GPa}$. 
Table 2. Plasticity and Elasticity parameters

\begin{tabular}{cc}
\hline Parameter & Value \\
\hline Young Modulus $\left(\mathrm{E}_{\mathrm{c} i}\right), \mathrm{GPa}$ & 52.4 \\
\hline Dilatation angle (degree) & 54 \\
\hline Eccentricity & 0.1 \\
\hline $\mathrm{K}$ & 0.666 \\
\hline $\mathrm{f}_{\mathrm{b} 0} / \mathrm{f}_{\mathrm{c} 0}$ & 1.07 \\
\hline Viscosity parameter & 0.0 \\
\hline
\end{tabular}

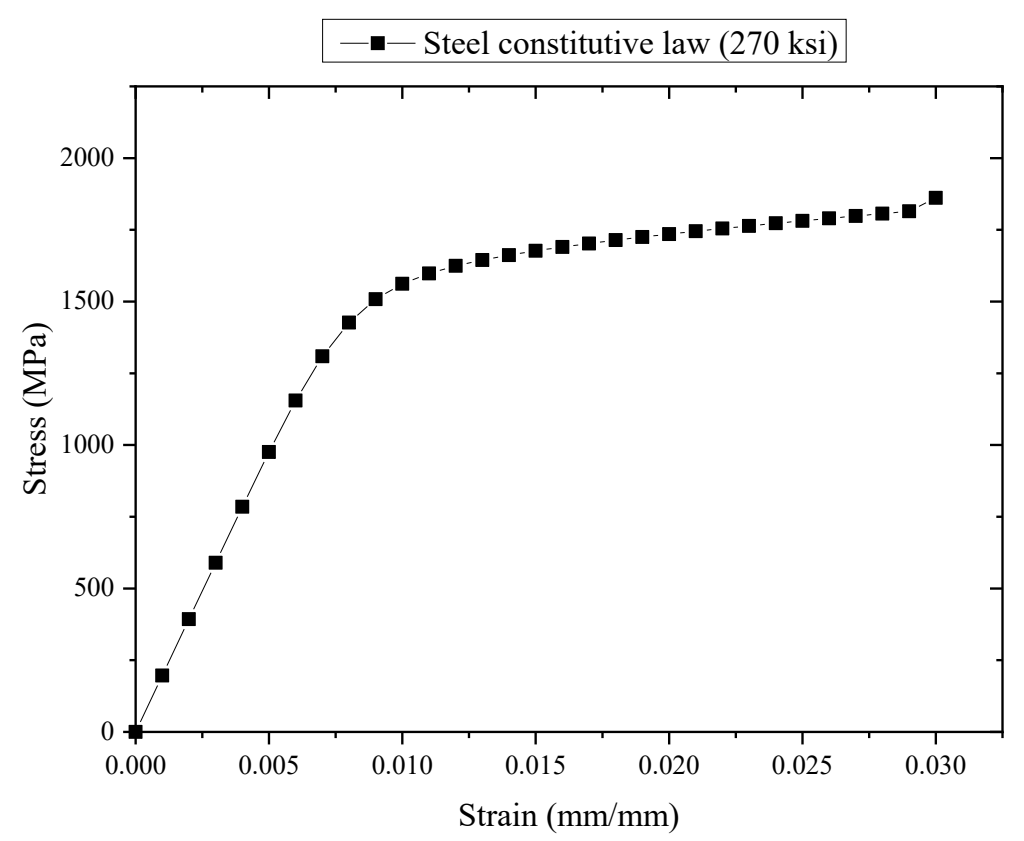

Figure 5. Steel bar constitutive law - ASTM 270

\subsection{Constitutive model (I-beams)}

For the three simulated I-beams (Figure $3 \mathrm{c}$ and $3 \mathrm{~d}$ ), the UHPFRC constitutive law written in terms of the inelastic strain is applied according to Figures $6 \mathrm{a}$ and $6 \mathrm{~b}$, and Krahl et al. [17], [18]. Plasticity and elasticity parameters are given in Table 2; the design parameters and prestress load are presented in Table 1.

\subsection{Boundary conditions, mesh, and load}

All beams were considered simply supported, and a 3D 8-nodes solid elements mesh was applied (C3D8R) to represent UHPFRC, with 3 degrees of freedom each node. Graybeal's girders were modeled with a $50 \mathrm{~mm}$ mesh size for transversal direction and $150 \mathrm{~mm}$ for longitudinal axis. I-beams were modeled using a $40 \mathrm{~mm}$ mesh size for longitudinal direction, and $20 \mathrm{~mm}$ mesh size for transversal discretization. 3D truss finite elements were used to represent the prestressed strands with a $100 \mathrm{~mm}$ mesh size. The gravity load was considered as $-9.81 \mathrm{~m} / \mathrm{s}^{2}$, and concrete density equals to $2500 \mathrm{~kg} / \mathrm{m}^{3}$. 


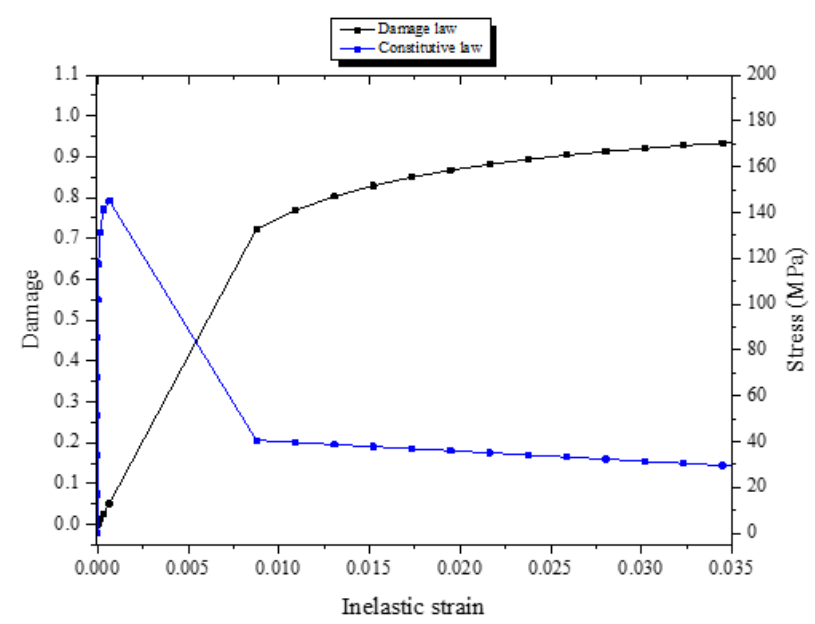

(a) Compressive uniaxial response

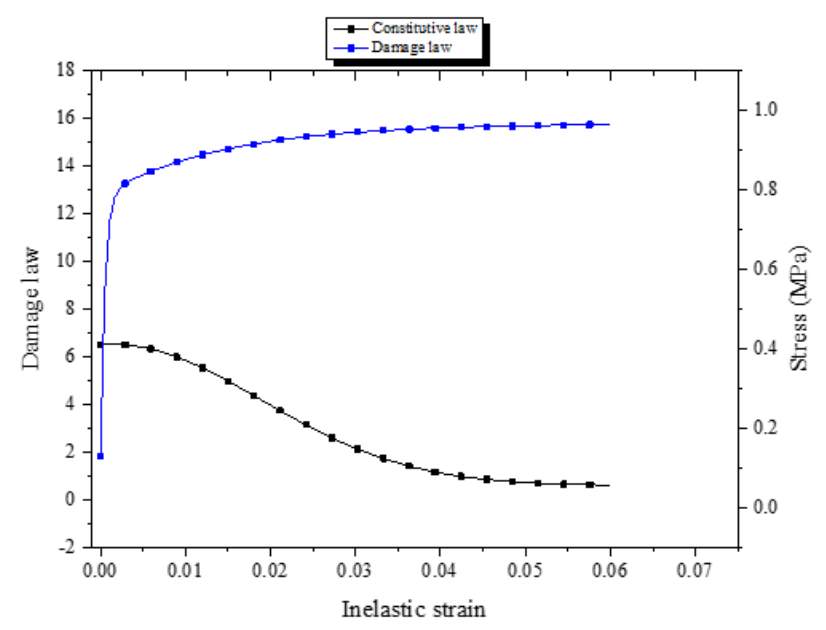

(d)Tensile uniaxial response

Figure 6. (a) e (d) UHPFRC constitutive model - Krahl et al. [17], [18]

A displacement control test was used for the three studied I-beams and for the Simplified Graybeal model. For the Complete Graybeal model, the same experimental methodology given in Graybeal [16] was performed, i.e., initial force control until $18 \mathrm{kN}$, and posterior displacements control until failure.

Therefore, the following cases were studied in this paper:

(I) Complete Graybeal model: force and displacements control, with constitutive law calibrated according to experimental results of Graybeal [16];

(II) Simplified Graybeal model: displacements control and simplified constitutive law based in the direct tensile tests;

(III) I-beams: displacement control and constitutive law was given by Krahl et al. [17], [18].

\section{RESULTS}

\subsection{Garybeal's girders - Numerical Validation}

Figure 7a presents the comparison between the numerical results and experimental behavior given by Graybeal [16]. The force-displacement curve obtained by the complete Graybeal model presented a 5\% maximum error (gray area in 
the graph). The estimated maximum force was $3.17 \%$ higher in the numerical model. The displacements prediction was $5.6 \%$ higher in the numerical model. For the Simplified Graybeal model, a maximum error of $10 \%$ was achieved in the force $\mathrm{x}$ displacement curve comparing the numerical and experimental results.

The experimental maximum bending moment $\mathrm{was}_{\mathrm{rd}}=4318 \mathrm{kN} \cdot \mathrm{m}$ [16]; the estimated values using the numerical approach were $\mathrm{M}_{\mathrm{rd}}=4455 \mathrm{kN} \cdot \mathrm{m}$ (Complete Graybeal model) and $\mathrm{M}_{\mathrm{rd}}=4000.4 \mathrm{kN} \cdot \mathrm{m}$ (Simplified Graybeal model).

Relevant parameters are the tensile and compressive damage indexes (Figure $7 \mathrm{~b}$ and $7 \mathrm{c}$ ) over the load evolution. Yang et al. [21] showed that damage indexes are used to predict the cracking zones, which can be useful for the identification of the failure modes. For the Graybeal's girders bending failures were observed, presenting predominant tensile damage indexes in the middle of the spans. When the peak force is reached, both models presented tensile damage indexes of $90 \%$ (Figure $7 \mathrm{c}$ ), with excessive strains in the reinforcements, characterizing the flexural failure.

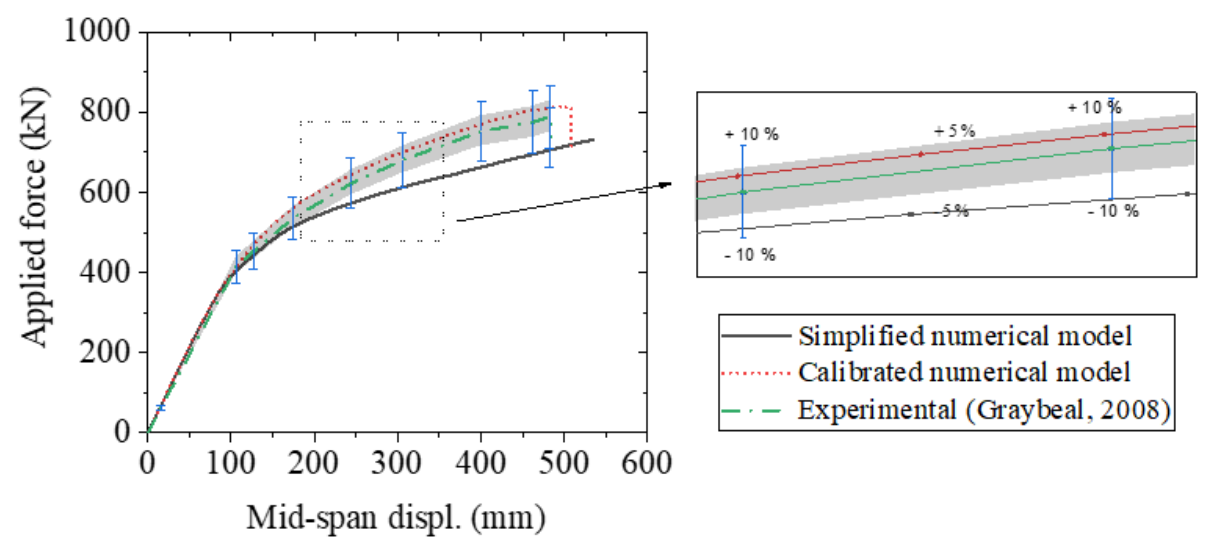

(a) Force-displacement

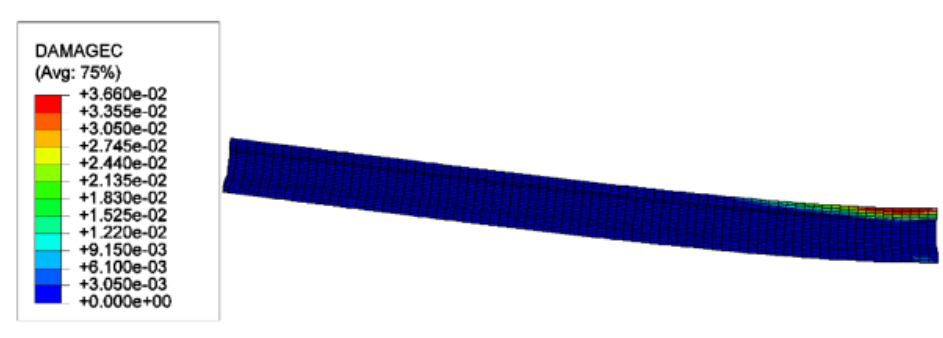

(b) Compressive damage (1/2 span)

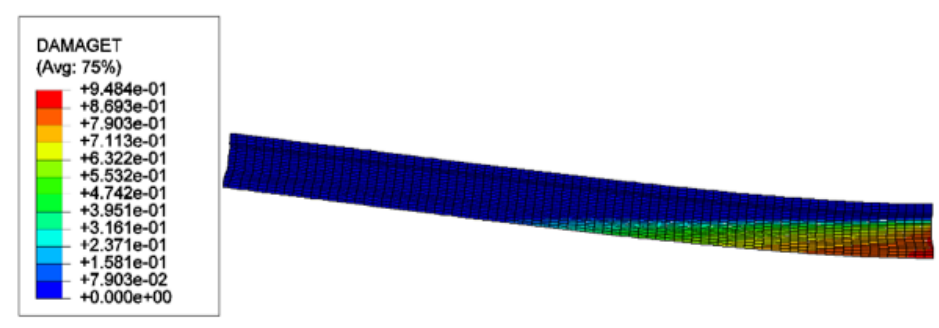

(c) Tensile damage (1/2 span)

Figure 7 - Damage behavior of AASHTO PCI SII 


\subsection{Analytical design of Graybeal's girder}

The analytical equations showed in section 2 are used to estimate the maximum bending moment of Graybeal's girders. Table 1 presents the material characteristics applied to prestress force and section parameters. Figure 8 presents a geometrical law in terms of the depth of the neutral axis and the compressed area, used in Equations 13 to 16. For the analytical design, better results were obtained with the tensile strength of $9 \mathrm{MPa}$.

The maximum strain in the compressive behavior is given by Equation 10, following the French Association of Civil Engineering (AFGC) [22]:

$$
\varepsilon_{c u d}=1+14 \cdot\left(\frac{f_{c t m}}{f_{c m}}\right) \cdot \varepsilon_{c 0 d}=5.8 \cdot 10^{-3}
$$

In Equation 10, $\mathrm{f}_{\mathrm{ctm}}$ is the tensile strength, which could be higher than cracking stress when UHPFRC presents strain-hardening behavior; $\mathrm{f}_{\mathrm{cm}}$ is the average compressive strength; $\varepsilon_{\mathrm{cod}}$ is the strain written in terms of the elastic limit $\left(\mathrm{f}_{\mathrm{cm}} / \mathrm{E}_{\mathrm{c}}\right)$, and $\mathrm{E}_{\mathrm{c}}$ is the young modulus initial tangent.

The calculus of $\varepsilon_{\text {cud }}$ allows the determination of the limit between strain domains 2 and 3 of the Brazilian code ABNT NBR 6118:2014 (i.e., concrete with a strain of 5.8\%o and steel strands with $10 \%$ ). The determination of the neutral axis between dominium 2 and 3 (i.e., $\mathrm{x}_{\text {lim }}$ ) is given by Equation 11:

$x_{\text {lim }}=\frac{\varepsilon_{c c}\left(h-d_{i n f}^{\prime}\right)}{\varepsilon_{c c}+\varepsilon_{s t}}=0.297 m$

The transversal section was divided into strips of $0.01 \mathrm{~m}$ heigh to account for the cumulative areas. Through the geometrical law, the geometrical law, it was possible to determine the values of $A_{c}=0.076 \mathrm{~m}^{2}$ (compressed area), and $\mathrm{A}_{\mathrm{t}}=0.154 \mathrm{~m}^{2}$ (tensile area) for the strain domain limit 2 and $3\left(\mathrm{x}_{\lim }\right)$; the force components for this configuration are expressed by Equation 12 to 15 :

$F_{c c}=0.5 \cdot A_{c c} \cdot f_{c}$

$F_{s c}=n_{\text {bar }, \text { top }} \frac{\pi \phi^{2}}{4} f_{p}\left(\varepsilon_{\text {prev }}+\varepsilon_{c}\right)$

$F_{s t}=n_{\text {bar }, \text { bot }} \frac{\pi \phi^{2}}{4} f_{p}\left(\varepsilon_{\text {prev }}+10 \%\right.$ )

$F_{c t}=0.9 \cdot\left(A_{t o t}-A_{c c}\right) \cdot 0.9 \cdot f_{c t}$ 


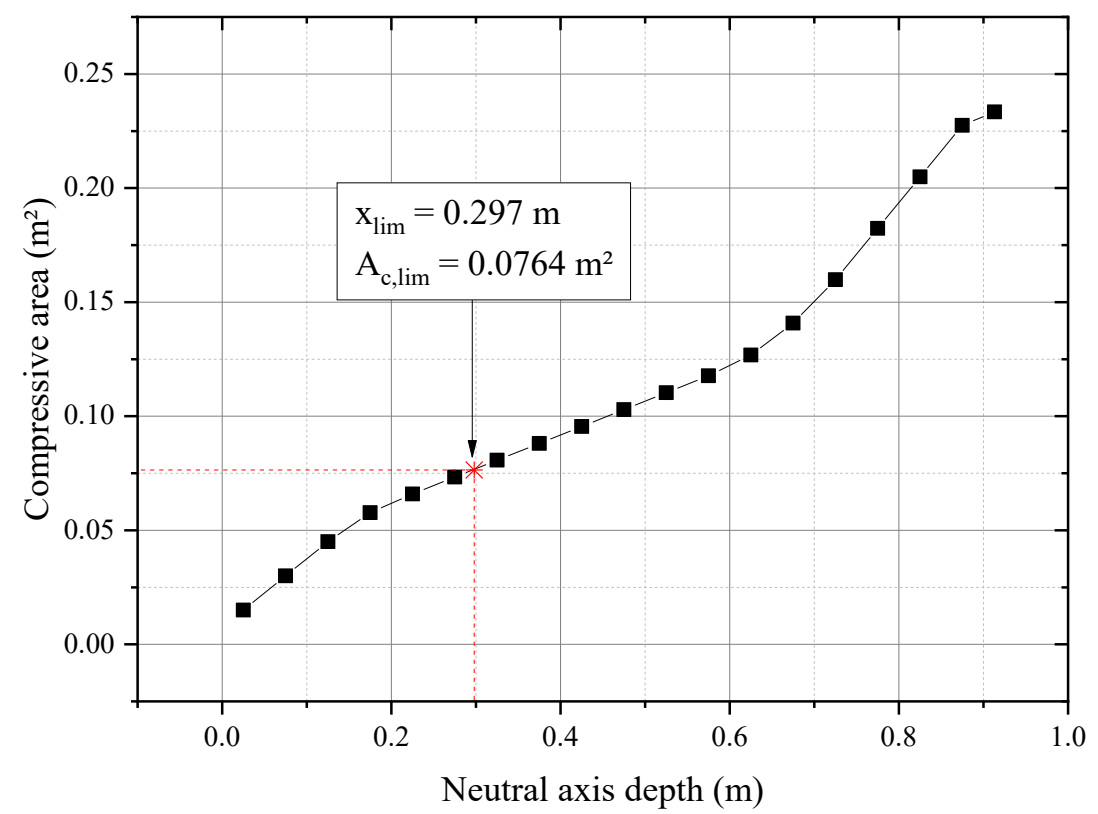

Figure 8. Geometrical law - Compressive area vs. Neutral axis depth (PCI AASHTO type SII)

In Equations 12-15, $\mathrm{A}_{\mathrm{cc}}$ is the concrete compressed area, $\mathrm{n}_{\mathrm{bar}}$ is the total number of strands, $\mathrm{A}_{\mathrm{tot}}$ is the total area of the cross-section, $f_{p}$ is the stress considering the total stress at strands, $f_{c}$ is the compressive strength; $f_{c t}$ is the direct tensile strength; $\varepsilon_{\text {prev }}$ is the previous strain in the prestressed strands, equals to $4.5 \%$ (for $f_{p i}=885 \mathrm{MPa}$ ), $\mathrm{f}_{\mathrm{p}}$ is the stress in the strands.

Table 3 presents the initial parameters obtained with Equations 13-16 using $\mathrm{x}=\mathrm{x}_{\text {lim }}$, establishing the equilibrium of forces in the cross-section, it is possible to determine the imbalanced vector $\Delta \mathrm{R}$ that governates the position of the neutral axis to ensure the balance until $\Delta \mathrm{R}$ approaches zero.

Table 3. Design data for Graybeal beam

\begin{tabular}{cc}
\hline Forces & {$[\mathbf{k N}]$} \\
\hline Rcc (lim) & 14796 \\
\hline Rsc (lim) & 274 \\
\hline Rst (lim) & 4939 \\
\hline Rct (lim) & 1979 \\
\hline$\Delta R$ (initial) & 9328 \\
\hline Rcc (final) & 5669 \\
\hline Rsc (final) & 411 \\
\hline Rst (final) & 4939 \\
\hline Rct (final) & 1141 \\
\hline$\Delta R$ (final) & 0.09 \\
\hline
\end{tabular}


In this way, for each iteration of $\Delta \mathrm{R}, \mathrm{A}_{\mathrm{cc}}, \mathrm{A}_{\mathrm{st}}, \varepsilon_{\mathrm{c}}$, and $\varepsilon_{\mathrm{st}}$ are updated. The values of $\mathrm{R}_{\mathrm{cc}}$ (force in concrete), $\mathrm{R}_{\mathrm{sc}}$ (force in compressed reinforcements), $\mathrm{R}_{\mathrm{st}}$ (force in tensile reinforcement), and $\mathrm{R}_{\mathrm{ct}}$ (force in tensile concrete) for the initial and final $\Delta \mathrm{R}$ are presented in Table 3. Evaluating the neutral axis final position, it was possible to verify that the prestressed strands are working with strains equals to $\varepsilon_{\mathrm{st}}=\varepsilon_{\text {pnd }}+10 \%=15.02 \%$, following the hypothesis of domain 2 . The resistant bending moment of cross-section is obtained by Equation 16:

$$
\begin{aligned}
& M_{r d}=A_{c c} \cdot f_{c d} \cdot\left(\frac{2}{3}\right) \cdot x+R_{s c}\left(x-d^{\prime}\right)+A_{c t} 0.9 \cdot \eta \cdot f_{c t} 0.9(h-x)+ \\
& \ldots+\sum_{n=I}^{26 \text { bars }} \frac{\pi \phi^{2}}{4} f_{p} \cdot Y_{i}
\end{aligned}
$$

In Equation 16, $\mathrm{Y}_{\mathrm{i}}$ are the distances of gravity center of prestressed steel strands to the neutral axis of the beam;

Finally, the strength bending moment of $4527 \mathrm{kN} \cdot \mathrm{m}$ was obtained through the analytical design equations. This value is very close to the experimental value obtained by Graybeal [16] and the numerical simulation developed in this paper $(4318 \mathrm{kN} \cdot \mathrm{m})$, with a $4.7 \%$ error.

\subsection{I-beams}

Figure 9 presents the force-displacement of I-beams (see the simulation condition in Figure $3 \mathrm{c}$ and $3 \mathrm{~d}$ ). It is possible to verify the high ductile behavior of the beams, showing high displaceable capacity until the total loss of strength.

Figures $9 \mathrm{~b}$ and $9 \mathrm{c}$ show the tensile and compressive damage distribution for the I-beam section with $\mathrm{h}=400 \mathrm{~mm}$ and $b=300 \mathrm{~mm}$. It can be noted a high level of tensile damage in the inferior zone at the center of the span, characterizing the bending failure mode. Nevertheless, it is also possible to detect the presence of tensile damage at the diagonals around the supports, showing the influence of the bending-shear composed failure mode, probably due to the minor span/height relation $(\mathrm{L} / \mathrm{h})$ in comparison with Graybeal's girder.

Equations presented in Section 2 were used to predict the maximum bending moment of the designed sections. Figure 9d presents the comparison of analytical bending moments and the values obtained through the numerical simulation. There is a correspondence between the numerical and analytical results that can be achieved, showing the accuracy of the proposed model given by Fehling et al. [7], [15] and adapted by this paper. 


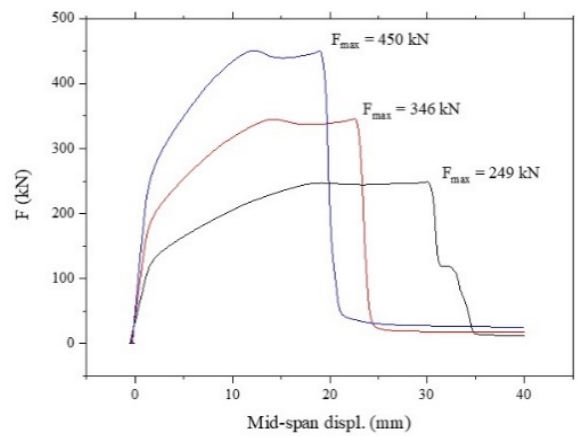

(a)
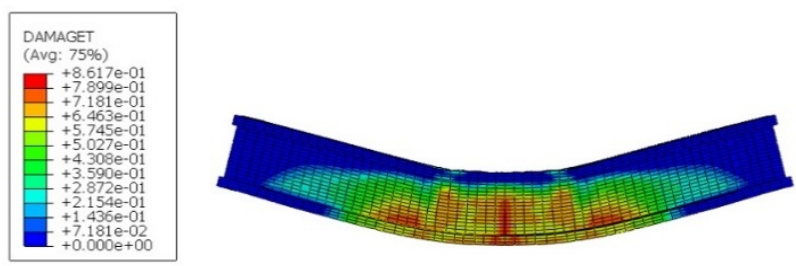

(b)
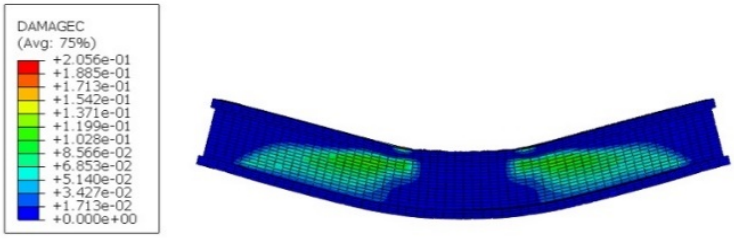

(c)

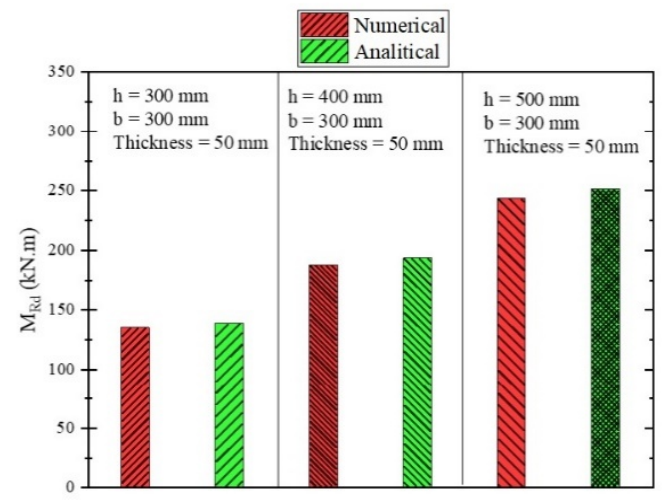

(d)

Figure 9. Prestressed I-Girder - Parametrical analysis: (a) Force-displacement, (b) tensile damage, (c) Compressive damage, (d) Comparison of bending moments

\section{CONCLUDING AND REMARKS}

This paper approaches the numerical modeling and design of prestressed UHPFRC I-beams subjected to flexural tests. The main aspects can be highlighted:

- The potential of concrete damage plasticity constitutive model was demonstrated to application in UHPFRC prestressed beams, presenting correspondence with the experimental results of Graybeal [16] for the PCI AASHTO SII beams; 
- The strength bending moments obtained by the analytical design equations showed to be accurate to predict the experimental and numerical results, with $5 \%$ error;

- A qualitative analysis shows the high strength and satisfactory ductile behavior of beams, with high energy dissipation before the failure;

- Due to the high span/height relation, the Graybeal's girders presented a typical flexural failure. For the I-beams studied, with reduced $\mathrm{L} / \mathrm{h}$ coefficient, it was possible to observe a composed bending-shear failure mode;

- The numerical simulation developed in this paper presented high accuracy, showing an error of $5 \%$ in the prediction of strength for Graybeal's girders and I-beams.

- The simplified Graybeal model presented an error of $10 \%$, estimating the maximum force strength. This difference evidences the latent influence of experimental variability between uniaxial sample tests and real structure behavior. The Brazilian code ABNT NBR 6118:2014 does not present the prescriptions for to design of prestressed and nonprestressed UHPFRC sections. In this way, this paper proposes a simple procedure to be applied at the design of prestressed beams subjected to bending loads.

\section{REFERENCES}

[1] P. Richard and M. Cheyrezy, "Composition of reactive powder concretes," Cement Concr. Res., vol. 25, no. 7, pp. 1501-1511, 1995, http://dx.doi.org/10.1016/0008-8846(95)00144-2.

[2] P. Cheyrezy, "Richard, reactive powder concretes with high ductility and 200-800 Mpa compressive strength," Spec. Publ. ACI., vol. 144, 1994, http://dx.doi.org/10.14359/4536.

[3] A. Ali, Behaviour of Prestressed Ultra-High Performance Concrete I-Beams Subjected to Shear and Flexure. Ottawa: University of Ottawa 2013.

[4] K. Habel and P. Gauvreau, "Response of ultra-high performance fiber reinforced concrete (UHPFRC) to impact and static loading," Cement Concr. Compos., vol. 30, no. 10, pp. 938-946, 2008, http://dx.doi.org/10.1016/j.cemconcomp.2008.09.001.

[5] P. Richard, M. Cheyrezy, S. D. Bouygues, and S. Quentin, "Composition of reactive powder concrexes," Cement Concr. Res., vol. 25, no. 7, pp. 1501-1511, 1995, http://dx.doi.org/10.1016/0008-8846(95)00144-2.

[6] T. Zdeb, "Ultra-high performance concrete - properties and technology," Bull. Polish Acad. Sci., vol. 61, pp. 183-193, 2013, http://dx.doi.org/10.2478/bpasts-2013-0017.

[7] E. Fehling, M. Schmidt, J. Walraven, T. Leutbecher, and S. Fröhlich, Ultra-High Performance Concrete UHPC. Berlin: Ernst and Sohn, 2014.

[8] F. Larrard and T. Sedran, "Optimization of ultra-high-performance concrete by the use of a packing model," Cement Concr. Res., vol. 24, no. 6, pp. 997-1009, 1994, http://dx.doi.org/10.1016/0008-8846(94)90022-1.

[9] K. Hanna, G. Morcous, and M. Tadros, "Effect of supplementary cementitious materials on the performance of concrete pavement," J. Mater. Civ. Eng., vol. 26, no. 4, pp. 789-793, 2014, http://dx.doi.org/10.1061/(ASCE)MT.1943-5533.0000862.

[10] H. G. Russell and B. A. Graybeal, Ultra-High Performance Concrete: A State-of-the-Art Report for the Bridge Community. McLean, VA: U.S. Department of Transportation, 2013.

[11] D. Wang, C. Shi, Z. Wu, J. Xiao, Z. Huang, and Z. Fang, "A review on ultra high performance concrete: Part II. Hydration, microstructure and properties," Constr. Build. Mater., vol. 96, pp. 368-377, 2015, http://dx.doi.org/10.1016/j.conbuildmat.2015.08.095.

[12] A. Spasojević, "Structural implications of ultra-high performance fibre-reinforced concrete in bridge design," M.S. thesis, Ec. Polytech. Fed. Lausanne, Suisse, 2008.

[13] T. M. Ahlborn, E. J. Puese, and D. L. Misson, Ultra-High Performance Concrete for Michigan Bridges: Material PerformancePhase I. Michigan: Michigan Dept. Transp., 2008.

[14] M. Rebentrost and G. Wight, "Experience and applications of ultra high performance concrete in Asia," in Proc. 2nd Int. Symp. Ultra High Perform. Concr., 2008, pp. 19-30.

[15] T. Leutbecher and E. Fehling, "A simple design approach for UHPFRC in bending," in RILEM-fib-AFGC Int. Symp. Ultra-High Perform. Fibre-Reinf. Concr., 2013, pp. 509-518.

[16] B. Graybeal, "Flexural behavior of an ultrahigh-performance concrete I-girder," J. Bridge Eng., vol. 13, no. 6, pp. 602-610, 2008, http://dx.doi.org/10.1061/(ASCE)1084-0702(2008)13:6(602).

[17] P. A. Krahl, G. M. S. Gidrão, and R. Carrazedo, "Compressive behavior of UHPFRC under quasi-static and seismic strain rates considering the effect of fiber content," Constr. Build. Mater., vol. 188, pp. 633-644, 2018., http://dx.doi.org/10.1016/j.conbuildmat.2018.08.121.

[18] P. A. Krahl, R. Carrazedo, and M. K. El Debs, "Mechanical damage evolution in UHPFRC: Experimental and numerical investigation," Eng. Struct., vol. 170, pp. 63-77, 2018, http://dx.doi.org/10.1016/j.engstruct.2018.05.064. 
[19] V. Birtel and P. Mark, "Parameterised finite element modelling of RC beam shear failure," in Ababqus User's Conf., 2006, pp. 95108.

[20] R. K. Devalapura and M. K. Tadros, "Stress-strain modeling of 270 ksi low-relaxation prestressing strands," PCI J., vol. 37, no. 2, pp. 100-106, 1992, http://dx.doi.org/10.15554/pcij.03011992.100.106.

[21] I. H. Yang, C. Joh, and B.-S. Kim, "Structural behavior of ultra high performance concrete beams subjected to bending," Eng. Struct., vol. 32, no. 11, pp. 3478-3487, 2010, http://dx.doi.org/10.1016/j.engstruct.2010.07.017.

[22] AFGC, "Ultra high performance fibre-reinforced concretes recommandations," in $A F G C, 2013$.

Author contributions: Contribution description of each co-author for the study. [GSMG: conceptualization, writing, methodology, investigation, review \& editing; PAK: conceptualization, writing, methodology, investigation, review \& editing; RC: supervision, conceptualization, writing, methodology, investigation, review \& editing.]

Editors: Bernardo Horowitz, José Luiz Antunes de Oliveira e Sousa, Guilherme Aris Parsekian. 